\title{
Türkiye'de Oyun Yazarlığında Yeni Eğilimler IV
}

\author{
Murat Mahmutyazıcıoğlu, Sami Berat Marçalı
}

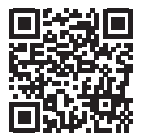

\section{ÖZ}

İstanbul Üniversitesi Haldun Taner Tiyatro Uygulama ve Araştırma Merkezi'yle, Tiyatro Eleştirmenliği ve Dramaturji Bölümü'nün ortaklaşa düzenlediği ve her yıl Mart ayına denk getirmeye çalıştığımız Haldun Taner'i Anma Toplantıları́nın IV. oturumunu gerçekleştireceğiz. Bu toplantıların başlığını "Türkiye'de Oyun Yazarlığında Yeni Eğilimler" şeklinde belirlemiştik. Bu söyleşilerde, 2000 yılından günümüze, oyun yazarlığını ve oyun yazarlarının sorunlarını; 2000 sonrası yazarların Türkiye tiyatro tarihiyle olan bağlarını/ilişkilerini konuşmaya çalışıyoruz. Bu oturumun moderatörü Ozan Ömer Akgül, konuşmacılar ise Murat Mahmutyazıcıoğlu ile Sami Berat Marçalı olacak.

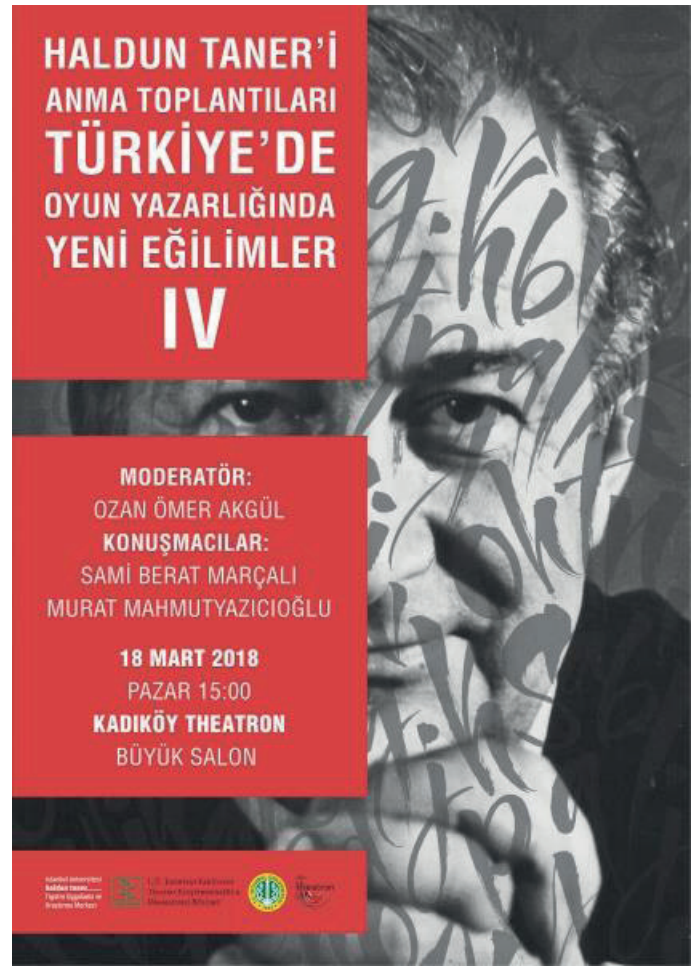


Ozan Ömer Akgül: Bugünkü konuklarımız Sami Berat Marçalı ve Murat Mahmutyazıcıoğlu. Bu konuşmalara 2015 yılında başladık ve toplamda üç oturum gerçekleştirdik. Konuşmacılar arasında Mirza Metin, Ebru Calkan, Ahmet Sami Özbudak, Şamil Yılmaz, Zeynep Kaçar, Hilal Kuvvet, Celal Ercan, Gülce Uğurlu, Cem Uslu, Gökhan Eraslan, Firuze Engin ve Ferdi Çetin vardı. Buradaki amacımız 2000 yılından sonra tiyatro yazarlığıyla uğraşanların hem envanterini tutmak -kimler yazıyor, kimler üretiyor- hem de bu yazarların Türkiye Tiyatrosuyla olan ilişkilerini ve beslendikleri dinamikleri öğrenmek. Bölüm Dergisi’nin 25. sayısında bu üç söyleşinin de deşifresini gerçekleştirdik. Söyleşileri kaçırmış olanlar dergiye İstanbul Üniversitesi Yayınları'nın web sitesinden ulaşabilirler. Amacımız bellek oluşturmak ve oluşturulmuş olanları kayıtlı tutmak. Aynı zamanda yaşadığımız dönemde kimler yazıyor ve oyun yazarlığg sürecinde ne yapıyorlar, hangi temaları kullanıyorlar, dertleri ne, nelerle uğraşıyorlar, bunları görebilmektir. Genelde yazarlara önceden birkaç soru gönderiyoruz. Söyleşi içinde bu soruları da soracağız, zaten kendileri de bir konuşma hazırladılar. Ayrı ayrı 15-20 dakikalık bir sürede kendilerini tanıtacaklar. Ardından hem benim sorularım hem de sizin sorularınızla bir sohbet havasında burada konuşma sürdürmeyi planlıyoruz.

Murat Mahmutyazıcıŏlu ile başlayalım. Murat, Marmara Üniversitesi Güzel Sanatlar Fakültesi İç Mimarlık bölümünden mezun. Sonra da Kadir Has Üniversitesi'nde Film ve Drama Anabilim Dalı'nda yüksek lisansa başlamış. Şekersiz, Fü, Aynur Hanım 'ın Bebeği, Sen Ístanbul'dan Daha Güzelsin ve Sevmekten Öldü Desinler adlı oyunları mevcut. Geçen yıl Sen Ístanbul'dan Daha Güzelsin adlı oyunuyla Afife'de Cevat Fehmi Başkut özel ödülünü almıştı.

Murat Mahmutyazıcıoğlu: Öncelikle kendi adıma teşekkür ederim. Hem Sami ile olmak çok keyifli hem de Theatron'da olmak çok önemli. Çünkü kendi yazım sürecimde bu topluluğu ve bu mekânı çok önemli bir yer olarak görüyorum. Burası, Sen Ístanbul'dan Daha Güzelsin oyununu oluştururken bana çok ilham vermişti. Biraz kendi serüvenimden bahsetmek istiyorum, 15 dakikayı bu amaçla kullanayım.

Tam olarak yazmaya ne zaman başladığımı çok hatırlamıyorum ama ilk oyunum Fü'nün ilk draftını 2012'de bitirmiştim. İlk yazdığım oyun Fü ama ilk sahnelenen oyunum Şekersiz. Fü, 2014 yılında İkincikat tiyatrosunda sahnelenmişti. Bu aslında bir yazarın nasıl başladığını anlatırken karışık bir durum oluyor. İlk yazdığım oyun ikinci sahnelenen oyunum ama ikinci yazdığım oyun ilk sahnelenen oyunum gibi.

İç mimarlık ve iş hayatı devam ederken tiyatro benim için bir lise tutkusu, küçüklük tutkusu ve aşkıydı diyebilirim. Tiyatroya geri dönmek için ilk olarak 2000'lerin başında Kadıköy Gençlik Merkezi'ne daha sonra 2005 yılında Şahika Tekand'ın Stüdyo Oyuncuları'na başladım. Belki oradaki eğitimi bilenler vardır; eğitimin sadece oyunculuk üzerine değil bir tasarım üretme ve farklı metinlerden faydalanıp bir şeyler yapmak üzerine de bir eğilimi var. Çok yönlü bir eğitim olanağı ve başka türlü bakmaya iten bir yapılanma var. Orada kendimizce denemeler yapıp 
hocalara göstermek için küçük küçük metinler oluşturuyorduk. Askerlik döneminden sonra hayatımın yirmi dört saatini tiyatroyla geçirmek gibi bir karara vardım. Çünkü mesleğimde çok mutlu değildim, yapmak istediğim şeyi yapamıyordum. Bunlar belki hepimizin yaşadığı çok klasik kaygılar ama bir karar vermek gerekiyordu. Önce oyunculukla başladım ve Şahika Tekand'ın Stüdyo Oyuncuları'nda birkaç oyunda oynadım. Sonrasında Tiyatro Boyalıkuş'la ve sonra da İkincikat'la tanıştım. İstiklal Caddesi'ndeki İkincikat'ta Sami ile çok oyun yaptık. Sonra bana Sami'nin yazdı̆̆ 1 "Limonata” oyununu yönetmemi teklif ettiler. O zamanlar çok tatlı bir ekip olmuştuk. O deneyimle beraber kafamda bir yazma fikri belirmeye başladı.

Bir de o zamanlar Dot'un yaptığı İngiliz Tiyatrosu işlerini izliyorduk. Gündelik hayatın dertleri ile ilgilenen metinlerle tanıştım. Ve kafamda birtakım hikâyeler belirmeye başladı ama bunu tam olarak tiyatro metnine nasıl dönüștüreceğim konusunda bir fikrim yoktu. Şöyle oldu; oyun yönetirken ve oyunculara reji verirken belki de kendi kafamda, kendi ailemden örnekler veriyordum ve onlar kafamda bir süre depolandı. İlk oyun Fü böyle başladı. İki yaşlı kadının konuşması, sadece diyaloglar başladı. Bir akşam cesaretimi toplayıp arkadaşlarıma okuttum. Onlar da meseleyi çok sevdiler fakat üzerine çalışılması gerektiğini söylediler. Sami ile metin üzerinde iki üç ay çalıştık. O zaman dramatik olan ve sahne için değerli olanın ne olduğu konusunda tam olarak bilgi sahibi değildim. Belki hala öğrenme sürecindeyim. Ama bu benim için iyi bir başlangıç oldu. Çünkü sahnede kendi kelimelerinizi duyduğunuz anda motivasyonunuz yükseliyor. Oyunumun İkincikat'ta sahnelenmesi sürecine başladıktan sonra motivasyonum çok yükseldiği için Şekersiz'i yazmaya başladım. Onu da Yan Etki tiyatrosunda yaptık ve Fü'nün ertelenmesiyle beraber ilk sahnelenen metin Şekersiz oldu. Yanetki'nin o zamanki sahnesi Asmalı Sahne'de hem yönettim hem de oyunculardan biri oldum.

Sonra 2014 yılında Fü, tiyatro festivalinde sahnelendi. Oyunu tüm turnelerinde ve İstanbul'da izledim. Seyircilerin tam olarak neye tepki verdiklerini ya da neye tepkisiz kaldıklarını gördüm. Bir süre sonra benim için çok değerli olan bazı şeylerin, sahne için, oyuncu için tam olarak o kadar da önemli olmadığını fark ettiğim anlar oldu.

2015 yılında İkincikat yaz projesi sebebiyle bana bir oyun sipariş etti. Yönetmen belliydi, Oğuz Arıcı'ydı ve ben 2-3 ay içinde kadına şiddetle alakalı bir metin ortaya çıkardım. O metnin oyuncularla ve Oğuz Arıcı ile karşılaşması benim için önemli bir başlangıç oldu. Çünkü Oğuz Arıcı, "Ben olmasam oyuncular zaten bu metni oynar." gibi bir cümle söylemişti ve bu o zaman çok ağır gelmişti. Kısıtlı bir sürede metni beraber çalıştıktan sonra anladım ki benim için çok önemli olan şey, sahne ve seyirci için çok da önemli olmayabilir. Asıl dramatik olan değerlidir ve kendi kafamızda kurduğumuz espriler metinde sadece basit bir geyik olarak kalabilir vs... Bu benim için çok yararlı olmuştu.

Fü ve Şekersiz daha "gerçekçi” bir senaryoya sahip, sahne üzerinde dizilere göz kırpan bir gerçeklikleri var. Onları da çok severim ama sahne gerçekliğini, tiyatro malzemesini daha fazla kullanmak gibi kaygılarım başlamıştı. Sen Ístanbul'dan Daha Güzelsin fikri başladığı zaman 
"Acaba biçim olarak farklı ne yazabilirim" diyerek bir araştırma sürecine girdim. Tamamen anlatıya göz kırpan bir metin oluşturmaya çalıştım. Daha sonra metin "Üç kadın sandalyede otururlar" şeklinde başladı. İstanbul'u merkeze alarak üç kuşak -bir anneanne, anne, ve kız üçgeninde- üç kadın temsilci ortaya çıktı. Hem kuşak çatışmasını ve kuşaklar arası ilişkiyi hem de yaşadıkları elli yıllık süreçte İstanbul'un değişimini yazmaya çalıştım.

Sonra "Böyle bir metin yazdım oynar mısınız" diyerek üç arkadaşıma danıştım. Prova sürecinden sonra da -Başak, Ayfer, Melis- oyuncuların baş harflerinden BAM tiyatrosunu kurduk beraber. Aslında bu başlarda metnin sahnelenme serüveninde etiket olsun diye koyduğumuz bir isimdi. Fakat seyirciyle buluşunca bizim de beklemediğimiz bir etkisi oldu. Hepimizin iki sezon boyunca çok şey öğrendiği bir iş oldu. Geri dönüşleriyle beraber oyuncular açısından da bakarsam, hem oyunculuklarına hem yönetmenliğime hem de yazarlığıma çok şey kattı. Aslında sanki meseleye bir başkasının gözünden tekrar bakıyormuş gibi hissettiğim bir süreç oldu. Benim için çok öğretici ve eğiticiydi. Kitaplar açıldı tarihte neler olmuş diye. Anlatının sınırlarını öğrendiğim, kendimi oldukça geliştirdiğim bir süreç içine girdim.

Sen Istanbul'dan Daha Güzelsin serüveni devam ederken Emek Sahnesi'nden bir teklif geldi, müzikli oyun yazmamı istediler. O zaman da Sevmekten Öldü Desinler 'i yazdım. Metin akarken, oyuncular oynarken, bunun bir yazar tarafından yazıldığ 1 ve yazarın kendisiyle dalga geçtiği; oyuncuların söylediği kelimelere yabancılaştığı, karakterin içinden çıkıp, anlatıcı oldukları, biraz da altı kalın çizilmiş kabareye göz kırpan bir oyun yazmaya çalıştım.

Şimdilik serüvenim bu kadar. Bundan sonra da özellikle geleneksel tiyatromuza ya da belki ortaçağ tiyatrosuna bakıp anlatının sınırlarını bir yazar olarak daha ne kadar genişletebilirim, buna bakacağım. Sen İstanbul'dan Daha Güzelsin'de ya da Sevmekten Öldü Desinler'de yapmaya çalıştığım şeyi daha ne kadar genişletebilirim, ne kadar uğraşabilirim üzerinde çalışıp görmek istiyorum.

Ozan Ömer Akgül: Sami Berat Marçalı da Yıldız Teknik Üniversitesi’nden mezun oldu. 2010'dan beri yönetmenlik, çevirmenlik ve yazarlık yapıyor. B Planı adlı bir grubu var. Yazdığı oyunlar arasında Küçük, Limonata, Sürpriz, Altı Buçuk ve son yazdığı Yuva isimli oyunu mevcut ki bu da geçen yıl New York'ta Laguardia Performing Arts Center'da prömiyer yaptı.

Sami Berat Marçalı: Yıldız Teknik Üniversitesi'nin amatör bir tiyatro topluluğu var, biz o zaman kısaca YÜO (Yıldız Üniversitesi Oyuncuları) diyorduk. Bütün serüvenim orada başladı. Oradaki ekiple araştırma yapıyorduk, çok araştıran bir ekiptir, biraz orada piştim diyebilirim. O dönemde oyunculuk ve yazarlık denemeye başladım. Üç yıl kadar onlarla birlikte oldum, Eric De Volder'in Oda ve Adam oyununu yönettim ve hiç beğenilmedi. Bir de oyun yazdım $K$ ış Geliyor adında ve o da hiç beğenilmedi. Sonra tiyatroya küstüm ve sinemaya geçiş yaptım. Bu arada endüstri mühendisliği okuyordum ama her zaman mühendis olmayacağımı bilerek devam ettim. Stajlarda gördüğüm kapitalizm hiç hoşuma gitmedi. Sonra New York Film Akademi’de 
altı ay kadar kısa film eğitimi aldım. Kurstakilerle beraber benim yazıp yönettiğim bir kısa film çektik. Yine çok kötü oldu. O dönemde kısa film ve uzun metraj senaryolar yazmaya başladım. Yıldız Teknik Oyuncuları'ndan ayrılan dört arkadaşım Tiyatro Sıfırnoktaiki adında bir grup kurmuştu. Tam beni çağırdıkları dönemde ekip dağılmış ve bir tek Emre kalmıştı. Diğerleri de fahri üye gibi kalmışlardı. "Gelip bizimle çalışmak ister misin? Kendimizce profesyonelleşmeye çalışıyoruz" dediler, ben de hiçbir şey düşünmeden sadece arkadaşlarım olduğu için kabul ettim. Metin araştırmaya başladık, o zamana kadar yazılmış ve basılmış metinlere ulaşabiliyorken o dönemden sonra Türkiye'ye gelmemiş olan metinleri araştırmaya başladık. Onk Ajans ile tanıştık. İngilizce kitaplar okumaya başladık. O dönemde çok oyun okuduk ve bir iki tane oyun seçtik. Bunlardan biri Açık Saçık Birkaç Polaroid'di. Bunu Emre yönetti. Bir diğer oyun da benim yönettiğim, Murat"'1n da başrolünde oynadığı Korku Tüneli oyunu oldu. Zaten Murat'la da o dönemde tanıştık.

2010 yılından itibaren tiyatro yapmaya başladım. O dönemde çok oyun okuyup incelediğim için, biraz da analitik zekâm olduğu için anlamaya başladım. Dramanın nasıl kurulması gerektiğine dair fikrim oluşmaya başladı. Çok oyun izlerim ve artık izlediğim şeyin metnini okuyabiliyordum. Küçük adında bir oyun yazdım. Bu oyunla da Interplay Uluslararası Genç Oyun Yazarları Festivali'ne kabul edildim. 18 farklı ülkeden 30 tane dramaturg, yönetmen, genel sanat yönetmeninin olduğu bir ortamda sizin oyunlarınız eleştiriliyor ve geliştirilmeye çalışılıyor. Orada biraz çalışkan öğrencilik yaparak normalde 5-6 hoca seninle ilgilenirken yaklaşık 20 hocadan fazlasına oyunumu okutabildim, hepsinden geri bildirim aldım. Sonra oyunu geliştirebilmek için bir sürü taslak yazdım. Karakterin nasıl yazılmasıyla alakalı ya da oyunun dramatik yapısının nasıl ilerleyeceği ile alakalı bir sürü şey öğrendim.

Tiyatro, özendiğim bir şeydi, sonrasında mesleğim oldu. Sonra Küçük yazıldığı gibi rafa kalktı. Ardından Limonata'yı yazdım. Bu arada yönetmenlik serüvenim devam etti ve bir şeyler daha yönettim. İkincikat’tayken yerli metin seçmeye karar verdiğimiz bir dönemde Aut ve Limonata'yı seçtik. Limonata'yı Murat"'n yönetmesine karar verdik ve sonra benim için Limonata devri başladi.

Bu süreç devam ederken İKSV'nin bir sonraki festival dönemine başvuru yapmak istedik. Hayatımızda ilk kez festivale başvuru yapacağız; benim sadece küçük bir fikrim vardı, bir sayfasını yazdığım bir şey. Festivale başvurunca kabul edildi. Ve bir anda süresi olan bir oyunu yetiştirme çabası içine girdim. Belki oyunu istediğim gibi yazdım ya da yazamadım ama Yalnızlar Kulübü o dönemde çıktı. Oyunu biraz oyuncularla da geliştirdik. İlk üç oyunum bu şekilde gelişti.

Sonra, Üst Kattaki Terörist'i uyarladım. Bu ilginç bir deneyimdi. Hayatımda yazarken en zorlandığım oyundur. Orijinal hikayeye bağlı kalmaya çalışırken bağımsız olmaya çalışıyorsun. Emrah Serbes'ten çok uzaklaşmadan ama kendimin de sözünü söyleyebileceğim bir hale 
getirmeye çalıştım. Güzel bir serüvendi. Yalnızlar Kulübü ve Üst Kattaki Terörist, İkincikat döneminde en fazla oynanan oyunlar oldu; seyircinin çok sevmesinden kaynaklı galiba.

Sonrasında Sürpriz ve Altı Buçuk'u yazdım. Bunları bir amaçla değil sadece kendi içimden geldiği için yazdım. Bunları da İkincikat döneminde sahneledik. Onlar da seyircisi en az olan oyunlardir.

Sonrasında da yaz oyunları projesi zamanında çıkmış olan Let adında bir oyun vardı; Özer Arslan'ın başlayıp benim devam ettiğim bir oyun. Onun fikrini alıp bütün her şeyi değiştirerek $P^{*} r k$ adlı bir oyun yazdım. Sonra da Yuva'yı yazdım. Amerika'dan Handan Özbilgin, -Laguardia Performing Arts Center'da genel sanat yönetmeni yardımcısı- bir Balkan projesi yapmaya karar verdikten sonra, Türkiye’yi Balkan ülkesi gibi gösterip bir sanatçıyla tanışmaya gelmiş, Özen Yula da beni önermiş. Handan bana sadece "Göç kavramı üzerinden bir oyun yapmayı istiyorum." dedi. Ben de Amerika'dan biri yönetsin ve iki oyuncu oradan iki oyuncu buradan olsun. Ben de yazarım," dedim. İki sene kadar sürdü. En az elli ya da altmış kez tekrar yazdırdılar. Sonra da Yuva ortaya çıktı.

Bu arada yazarlığa dair iki proje gerçekleştirdim. Biri \#Yarının Oyunları diğeri de \#SavaşVeBarışOyunları. İkisi de yaz projesi. Bu oyunlar yazın on kez oynanıp eğer içimize sinerse ya da seyirci isterse devam ettirilmesi kararlaştırılan oyunlardı. Bunlar arasında Firuz Engin; Cambazın Cenazesi, Deniz Madanoğlu; Poz, Halil Babür; Kasap oyunları vardı. Murat'ın, Aynur Hanım'ın Bebeği oyunu da bu proje kapsamında çıktı. Bunların bazıları sezonda da devam etti, hatta Kasap hala devam ediyor.

2016'da İkincikat'tan ayrıldım. Emre ile anlaşamadık. İkimizde gençtik ve olgunlaşmak istediğimiz bir dönemdeydik. Giden ben oldum ve B Planı adında bir grup kurdum. Geçen sene Ístila adlı bir oyun sahneledim. Bu sene de Tac' 'n Nöbetçileri ve kendi yazdığım Yuva'yı sahneledim. Şu anda özetle bu kadar.

Ozan Ömer Akgül: Özgeçmişinizi anlattınız biraz ayrıntılara da girelim. Yazma deneyimlerinizden bahsedin, onları da merak ediyoruz. İkiniz de aynı zamanda yönetmenlik yapıyorsunuz. Hem kendi metinlerinizi hem de başka metinleri yönetiyorsunuz. Yönetmenlik, yazarlığına nasıl bir katkı sağlıyor? Bir diğer soru da Türkiye Tiyatrosu bağlamında düşünecek olursak beğendiğiniz yazarlar var mıdır?

Murat Mahmutyazıcıoğlu: En başından beri yönetmenlik gibi bir iddiam hiç olmadı. Uzun oyun olarak üç oyun yönettim. Biri Sen İstanbul'dan Daha Güzelsin diğeri Şekersiz. Bunlar zaten kendi metinlerim. Ayrıca Sami’nin metnini yönettim, bir de Galata Perform'un okuma tiyatroları var.

Bir metni elime aldığım zaman ben bunu yönetebilirim gibi bir motivasyonum olmuyor. Sadece bir şey yazdığım zaman onu başkasına emanet etmek istemiyorum, kendim yönetmek 
istiyorum. Çünkü oyun bazen rejisiyle çıkıyor; Sen İstanbul'dan Daha Güzelsin oyununda olduğu gibi. Şekersiz de öyle çıktı. Yan Etki Tiyatrosu, Asmalı Sahne'deydi ve Asmalı Mescit'in bir apartman katındaydı. Metnin başlarından o mekâna yönelik yazmaya başladım; seyirciler şuradan girerler, burası onların oturma alanı olur, karakterler kavga ettikleri zaman içerideki odaya girerler gibi düşünerek yazmaya başladım. Rejisiyle yazılmış bir oyun. Bu nedenle onu bir başkasına anlatmak ve tekrar biçimlenmesini istemek gibi bir arzum olmadı. Sen Ístanbul'dan Daha Güzelsin oyunu da aynı şekilde ilerledi. Üç kadın sandalyede oturur... Bunu da aşağı yukarı rejisiyle yazdım ve "Bunu ben yöneteceğim başkasına gerek yok," diye düşündüm.

Leenane 'in Güzellik Kraliçesi oyunu beni çok etkilemişti. Oyunun tekinsiz hali her an sizi şaşırtabilir. Seyirci olarak bana ilk kez bir çivinin üzerinde oturuyormuş hissi veren oyun oldu. Ondan sonra -klasikleri saymazsak- kendi kuşağım olan yazarlardan çok beslendim. Örneğin Sami'nin Limonata'sı, Yiğit Sertdemir'in yazdıkları. Yazmaya başladıktan sonra izlediğim ve beni etkileyen oyunlar da var: Garaj, Medet, Poz gibi oyunlar. Ama başta Fü'yü yazarken etkilendiğim şey Leenane'nin Güzel Kraliçesi'ndeki diyalog tekinsizliği diyebilirim.

Sami Berat Marçalı: Serüvene yönetmenlikle başladım ve ilk oyunum sahnelenene kadar beş altı oyun yönettim. O döneme kadar sahne üzerinde olan dinamiği iyi kavradığımı düşünüyorum. Bunun elbette yönettiğim oyunlarla ilgili bir etkisi vardır ama kafamda hep ikisini ayırmaya çalışıyorum. Ne yönettiğim oyunları ne de yazdığım oyunları tekrarlamak istiyorum. Aslında -bunu negatif anlamda söylüyorum- bir şey yapıyorsam biricik olmalı. Örneğin şu an Yuva hiçbir şeye benzemeyen bir oyun; iki dilli, dilin \%70'i İngilizce ve göçmenlerle ilgili. Bir şey yazıyor ya da yönetiyorsun, o yaptığın şeyden yeni bir şey öğreniyorsun. O öğrendiğin şeyi tekrarlamak yerine, öğrendiğinden daha fazlasını ya da daha değişiğini nasıl bulabilirsin diye kafa yormaya başlıyorsun. Hayatımda Yalnızlar Kulübü gibi bir oyun okumadım. Örneğin Limonata o dönem Türkiye için cesur sahneler içeren bir oyundu. Belki o yüzden hala konuşabiliyoruz. Aile yapısını çökerten bir tarafı vardı. O zamana kadar bu kadar net bir şey söyleyen bir oyun olmadı ya da belki ben okumadım. Yönetmenlikle yazarlık birbirini besliyor ama yaptığım işleri beslemiyor. Tabi buna dışarıdan bakarak tam tersini de söyleyebilirsiniz.

Etkilendiğim yazarlar konusunda da samimi olmak gerekirse öyle çok etkilendiğim yerli yazar yok. Yazarın kendisinden etkilenmiyorum ama bazı oyunlarından etkilenebiliyorum. Örneğin Şamil Yılmaz'ın Avzer'inden çok etkilenmiştim. Ama mesela bir önceki oyunu Kadınlar Aşklar Şarkılar beni etkilememiş bir oyundu. Ahmet'in performansı çok öndeydi. Bunu kendisine de söylediğim için burada anlatabiliyorum. Berkun Oya'nın yazdığı oyunları zaman zaman sevmişimdir. Örneğin; Yangın Dua 'sı beni çok etkilemiştir. O zaman çok küçüktüm ve yeni yeni tiyatroyla tanışıyordum. Biçimi beni çok etkilemişti. Berkun bir daha öyle oyun yazmadı, daha realist oyunlara döndü. Yine Berkun'un Güzel Şeyler Bizim Tarafta ve Bayrak oyunu etkilemişti. 
Bir yandan da kendi arkadaşlarımla beraber yaptığım ve altında kendi imzamın olduğu oyunlar var. Yönetmesem bile oyunlarla haşır neşir olduğum için çok fazla yazarla birlikte çalıştım. Bence, Firuz Engin çok iyi bir yazar. Cambazın Cenazesi gayet iyi bir metin. Aynur Hanım'ın Bebeği bence Murat'ın yazdığı en iyi oyunlardan biri.

Açıkçası daha çok yabancı yazarlardan etkileniyorum. Martin McDonagh, çok etkilendiğim bir yazardır. Ama özellikle ilk dönemlerinden çok etkilenirim. Örneğin; Leenane ’in Güzellik Kraliçesi, Inishmorelu Yüzbaşı, Inishmaan Sakatı. Bu ilk dönem yazdığı oyunlar bence çok iyi oyunlar. Aynı şekilde Philip Ridley de beni çok etkilemiştir. Onun da zaten üç oyununu sahneledim. Ridley benim yazınıma çok şey katmıştır diye düşünüyorum. En çok etkilendiğim yazar Tony Kushner oldu. Angels in America bence tarihte yazılmış en iyi oyun. Bunu içine Shakespeare gibi klasikleşmiş yazarları da katarak söylüyorum. Burada ne kadar karşılığ 1 var emin değilim ama gerçekten benim çok etkilendiğim bir oyundur.

Özellikle yabancı yazarlarda şöyle bir şey var; belli başlı konular çok güncel. Özellikle 1rkçılık ve çocuk istismarı konusu. Evet, burada da bir karşılığı var ama oradaki kadar yok. Röportajlarına baktı̆̆ımda Tony Kushner, Angels in America'yı on senede yazmış. Bir oyun yazmak için on sene çok uzun bir süre ama defalarca ve tekrar tekrar yazarak geliştirmiş, sonunda da meyvesini yemiş.

Yerli yazarlar konusunda o kadar konuşamam ama şimdiki yabancı yazarlar biraz çocukça davranıyorlar. Hemencecik yazarak paket halinde bitiriyorlar. Karakterler biraz karton oluyor ve söylediği sözleri savunamayan oyunlarla karşılaşıyorum. Ya da beyin akışı gibi, bir konu hakkında bir şeyler hissediyor ama bir drama akışı derdinde değil ve kurgu yapmak istemiyor. Tweet yazar gibi oyun yazıyorlar. Bu da benim hiç hoşuma gitmeyen bir şey. Birkaç yazara söylediğim bir şey var; -buna Murat da katılır- blog yazarıyla oyun yazarı arasında bir fark var. Hatta tiyatro yazarlığı ve bütün yazarlıklar arasında bir fark var. Tiyatroyu edebiyatın içine koymuyorum; belki de tiyatronun canlı bir şey olmasından ve her an değişebilir olmasından dolayı. Bunu edebi bir hale dönüştürürken bunun bir bilinç akışı gibi yapılmaması gerekiyor. Üzerine biraz daha fazla çalışılması gerekiyor. Öteki türlüsü aklına gelen güzel replikleri yazmak gibi oluyor.

Murat Mahmutyazıcıŏglu: Sami’nin söylediklerini kendi sürecimde değerlendirmek istiyorum. Bir oyunla tanındıktan sonra, geçen seneden beri "Bu oyunu okur musun" gibi teklifler geldi. Ben de özellikle ilk kez yazılmış ya da ilk kez sahnelenecek oyunu okumayı çok severim. Fakat orada kendi serüvenimde de yaşadığım çıkmazı görünce anlıyorum ki masanın başına oturup çalışmak çok zor geliyor. Örneğin Fü’nün ilk taslağı tamamen konuşma diliyle yazılmıştı. Düzeltmeler bile bana çok zor gelmişti ve arkadaşlarıma o şekliyle okutmuştum. Oyunun sadece dil bilgisini düzeltmek benim için bir ay sürmüştü. Her sayfada neredeyse on tane sigara içiyordum. Çünkü zamanında yola masa başı iş yapmayacağım, tiyatro yapacağım 
diye çıkmıştım. Fakat yazdığınız şey, sonuçta bir oyun ve bunun bir sürü formülü var. Bu oyun yönetmenle, oyuncularla, tasarımcıyla ve sonra seyircilerle tanışacak. Üzerinde onunla çalışmak isteyen bir sürü göz olacak ve kâğıda yazdığınız şeyin anlaşılır olması gerekiyor. Gerçekten yapıyı iyi kurmanız gerekiyor. Bu benim de şimdi yavaş yavaş anladığım bir şey ve çalışmakla alakalı. Oturup yazacaksınız, çöpe atacaksınız, tekrar yazacaksınız. Taslak, taslak, taslak...

Okuduğum oyunlarda yazılanlara kendi düşüncem üzerinden eleştiri yaptığım zaman, karş1 tarafta bunun tam bir karşılığı olmadığını gördüm. Ben de ilk başlarda aynı şeyi yapıyordum. Tabi ki anlatmak istediğiniz bir hikayeye güveniyorsanız onun arkasında duracaksınız ama metnin derinleşmesi için masa başı çalışmasının çok iyi yapılması gerekiyor.

Yazma süreci giderek daha da zor geliyor, son bir senedir hiçbir şey yazmadım. Bu konuşmalar bana çok iyi geliyor çünkü insana şunu hatırlatıyor; bir oyun yazarken ilk motivasyonum neydi? Neden TV dizisi değil, kitap ya da şiir değil de bir tiyatro oyunu yazıyorum? Meseleye böyle bakınca, o zaman bir kelime ya da hayal ettiğimiz sahne ortaya çıkıyor. Anladığım kadarıyla bu hiç bitmeyecek bir serüven. Her oyun aslında sıfırdan başlamak; aynı oyunu yazmamak, aynı biçimi yapmamak için sürekli okuman, izlemen, düşünmen gereken, masaya oturup yazman gereken bir süreç.

Sami Berat Marçalı: Biz şanslı başladık. Birbiriyle iyi anlaşan ve birbirinin fikrine güvenen insanlarla beraberdik. O benim oyunumu, ben de onun oyununu okuyordum. Birbirimize kafa göz giriyorduk. Her ne kadar farklı yollara gitmiş olsak da, şu an ne kadar çok araştırma yapmamız gerektiğini biliyoruz. Yuva'yı yazarken Oğuz Arıcı'ya üç kez okuttum ve geri dönüş aldım. Psikologa okuttum. En az yirmi kez Handan'a okuttum. Baktığınız zaman ortada çok ciddi bir emek var. Sonra provaya başladığımızda da oyunu çok değiştirdim, muhtemelen kendim yönettiğim için. Murat'ın dediği şey çok önemli; hem masa başı çalışma yaparak hem dinleyerek ilerlemek gerek. Mutlaka etrafınızda güvendiğiniz birkaç kişi vardır ve onlara zorla okutun, çünkü okumuyorlar. Peşlerinden koşun ve insanları zorlayın. Size gelen eleştirileri iyi dinleyin. Birilerini iyi dinlediğiniz zaman kendinizi de daha iyi ifade edebilirsiniz.

Ozan Ömer Akgül: Soru ya da yorumlarınız varsa alabiliriz.

Soru: Son dönem yerli metinlerde anlatının çok tercih edildiğini görüyoruz. Bunun hem sizin açınızdan hem de genel açıdan bir değerlendirmesini yapabilir misiniz? Siz nasıl tercih ettiniz ve bunu genel olarak nasil buluyorsunuz?

Murat Mahmutyazıcıoğlu: Arka fonda oranın ev olduğunu belirtmek için ev resmi yapılmış ya da oranın oda olduğuna sizi inandırmak için üç kanepe konmuş oyunların dışında ne yapabilirim diye düşünmüşümdür. Sen İstanbul'dan Daha Güzelsin'i yazmadan bir süre önce farklı bir şey nasıl yapabilirim diye düşündüm. Anlatı yazara bence çok geniş bir alan veriyor. Hayal ettirebilmek açısından seyirciye çok büyük olanaklar sağlıyor. Sahnede sadece 
bir kişinin anlatımıyla yola çıktığınız zaman daha önce izlediğiniz ya da okuduğunuz ve size tiyatro olarak sunulan bütün klişelerinden kurtulmak gibi bir yola giriyorsunuz. $\mathrm{O}$ zaman mesafeler ve hiyerarşi kalkıyor ve seyirciyle bir şeyler paylaşıyormuş gibi oluyorsunuz. İşte tam da o zaman tiyatro oluyormuş gibi bir hissim var. Tabi ki piyasaya bu tür anlatı metinleri çıkıyor ama bunu genel olarak bir moda var gibi değerlendiremeyiz. Çünkü ne kadar kişiye ulaşıyor bilmiyoruz.

Sami Berat Marçalı: Anlatı metni yazmak ve yönetmek biraz moda oldu. Merak ediyor yazarlar ve belki de denemek istiyorlar.

Murat Mahmutyazıcıoğlu: Bizim kodlarımızda "Bu oyun ne anlatıyor" gibi bir şey var. Belki de hikâye anlatma geleneğinden geldiğimiz için başı, ortası, sonu belli olan bir şeyler görmek istiyoruz. Bu belki de Yeşilçam dramaları ya da TV dizilerinden kodlarımıza işlenmiş bir şey. Yazar ya da yönetmen olarak bir süre sonra başka bir şey yapmak istiyorsunuz. Belki oyuncu olarak da başka bir şey denemek istiyorsunuz. Bir tepki ya da bir ihtiyaç olabilir. Bunun formülünü tam olarak veremem ama sonuçta bizim geleneğimiz de anlatıya dayanıyor ve bundan besleniyor olabiliriz.

Sami Berat Marçalı: Bu sadece senle de alakalı bir şey değil. Sen dört duvar koy ve öyle yaz ama ben onu dört duvarsiz da sahneleyebilirim.

Murat Mahmutyazıcıoğlu: Tabi ki yönetmenin de bir alanı ve bir serüveni var. Çok gerçekçi yazılmış bir metni çok daha farklı bir biçimde de sahneleyebilir.

Ozan Ömer Akgül: Ama yazarken de bir stratejin var. Örneğin Sen Ístanbul'dan Daha Güzelsin 'i yaparken bir anlatı koduyla yapmak istedin. Hem anlatı kodunu hem de tiyatronun araçlarını kullanmak istedin ki bu da metinde var. Aslında senin Yuva oyunu sahnelemesinde de var. Tiyatronun araçlarını göstererek ve bunun altını çizerek yapıyorsun.

Sami Berat Marçalı: Evet, baktığınızda Yuva, dört duvarlı bir oyun ama ben dört duvarlı yapmak istemedim.

Ozan Ömer Akgül: Hem anlatı formu hem de yazar olarak senin bir biçim önerin gibi geliyor bana.

Murat Mahmutyazıcıoğlu: Yazmaya başlarken burada teatralliği vurgulayayım gibi bir şey yok ama ortaya çıkan şey bir şekilde sizi yönlendiriyor. Provaya başladıktan sonra metin yönetmene karşı çıkmaya ve değişmeye başladı hatta oynanmaya başladıktan sonra bile bu değişim sürdü. Yazdığım şeyle yönetmenliğim arasında bir çatışma yaşadım. Sahne çok karışık geldi çünkü metin parçalı ve sürekli zaman, mekân atlamaları olan bir metin. Çalışırken anlatılan şeyin oyuncu tarafından da içselleştirilmesi için gerçekçi bir sahne çalışıyormuş gibi yaptık; normal bir sahne provası gibi. Sonra aynı duyguyu oturarak anlatmalarını istedim. Bu hepimiz için bir araştırma süreciydi aslında ve metin de bana çok şey öğretti. 
Ozan Ömer Akgül: Başka soru ya da yorum var mı?

Soru: Epey bir oyun seyrettim. Sizin oyunlarınızın da hemen hemen hepsini izledim. Oyunların süresi hakkında bir şey sormak istiyorum. 70 ya da 80 dakika artık bu zamanda belli bir hıza ulaşmış insanlar için çok fazla. Neden yazarlar çok uzun yazıyorlar? Neden hala uzun oyunlar sahneleniyor diye merak ediyorum? Oyunlarınızı yazarken oyunculuğu da kafanızda kurguluyor musunuz? Çünkü artık oyuncularda beden dili çok önemli.

Sami Berat Marçalı: Buna katılıyorum. Uzun oyunlar bir noktadan sonra -eğer sahnede gerçek anlamda bir prodüksiyon yapmıyorsa- ilgiyi dağıtıyor. Ostermeier'in Hamlet'ini üç buçuk saat arasız, gözümü kırpmadan izledim. Hiç sıkılmadım, hiç de dikkatim dağılmadı. Ama orada çok ciddi bir zaman ve zeka var. Şu an biz yeni yeni geliştiğimiz için, biraz da desteklenmediğimiz için bir şeyler tam olmuyor. Bu yüzden katılıyorum, oyunlar özellikle 80 dakikanın üzerine çıktığı zaman artık bizi kaybediyor. Çünkü her şey çok hızlı, televizyon çok hızlı, telefonlar çok hızlı. Bu sebeple Yuva'yı 60 dakika yazdım. 60 dakikada olsun bitsin ve seyirciye bu kadarlık bir serüven yaşatsın istedim. Belki daha uzun olması gerektiğini düşünenler olacaktır. Ama benim, seyirciye bu kadar kısa sürede bir his yaşatma gibi bir hayalim olmuştu.

Ondan önce yazdığım oyun Altı Buçuk da 60 ya da 70 dakikaydı, çok uzun değildi. Biraz böyle yazmayı seviyorum, kelimelerimi boşa harcamayı sevmiyorum. Daha tasarruflu yazmaya çalışıyorum. Genel olarak yerli yazarlarda her şeyi anlatma hissiyatı oluyor. En beğendiğimiz oyunlar da iki saate yaklaşıyorlar ve yazdıkları şeyi atmaya kıyamıyorlar. Çünkü onların da bir anlamı olduğunu düşünüyorlar. Bunu çok iyi anlıyorum. Evet onların da bir anlamı var ama onu çıkardığında oyun o kadar da büyük bir şey kaybetmeyebilir.

Murat Mahmutyazıcıoğlu: Kendim izlerken sıkılacağım bir sürede oyun yazmamak gibi bir düşüncem oluyor başlarda. Ama bazen de olmuyor. Örneğin Sen İstanbul'dan Daha Güzelsin 75-80 dakika civarı ama Sevmekten Öldü Desinler 105 dakika. Biraz uzun fakat bu çağın hızlılığına ayak mı uyduracağız yoksa sahnede yaptığımız şey bu hızlılığa çomak sokmak mı diye bazen düşünüyorum. Üç saatlik bir oyun iyi yazılmış ve iyi araştırılmış bir oyunsa tabii ki izlenir diye düşünüyorum. Biraz düşüncelerim değişmeye başladı. Mesele 60 dakikalık oyun yazmak değil, tiyatro yapmaya çalışmak olmalıymış gibi geliyor. Seyirci telefonunu kapatacak 60-70 dakika oyuncu ile beraber bir oyunu paylaşacak ve sonra dişarı çıkacak. Sonra herkes kendi hayatına devam edecek.

Sami Berat Marçalı: Temelde söylenmesi gereken şey dramanın hak ettiği kadar süresinin olması gerektiği. Bir oyun 40 dakika da olabilir. Berkun'un Bomba's1 15 dakika. Onun projesi o kadar dakika hak ediyor, onu o kadar izletebiliyor. Bunu farkında olmakta fayda var. Yeni bir oyun okudum ırkçılık ve zencilik üzerine, oyun 315 sayfaydı. Neredeyse dört saatlik çok iyi bir oyun ama burada karşılığı yok. 
Ozan Ömer Akgül: Belki de karşılığı olabilir. Çünkü seyirciyi dönüştürenin yazar ve yönetmen olduğunu düşünüyorum. Birlikte dönüşüyoruz bu nedenle bir şeyi ortaya koymadan da bilemiyoruz.

Murat Mahmutyazıcıoğlu: Oyun yaparken prodüksiyonu da düşünüyorsunuz; özellikle de bağımsız bir ekipseniz her şeyi göz önünde bulundurmanız gerekiyor. Koşullar da yaptığımız şeyi biçimlendiriyor ve etkiliyor. Aynı oyunu farklı sahnelerde oynarken aynı 1şı̆̆ı yapamayacağımı bildiğim için "en az ne yapabilirim” diye düşünüyor insan. Yazarken tüm bunları düşünmek gerek. Oyunu İkincikat'ta yazmaya başlamıştım ama Theatron'da prova yapmaya başladığımız zaman ister istemez değişiklikler oldu. Çünkü insan yazarken mekanı hayal ederek yazıyor.

Soru: Bazı yönetmenler için en iyi yazar ölü yazardır. Siz yazar olarak buradaki özgürlük alanınızı ne kadar belirleyebiliyorsunuz? Yönetmenleri özgür bırakabiliyor musunuz?

Sami Berat Marçalı: Benim oyunlarımın her birini başka insanlar sahneledi. Ben galiba biraz inatçıyım ve yönetmenle çok mücadele ediyorum. Karakterlere bağlı olduğum için savaş veriyorum ve yönetmeni ikna edebildiğim ölçüde mutlu oluyorum. İkna edemediğim zaman da yönetmene bırakıyorum. Diğer bir yandan yönetmenliğini yaptığım oyunlarda değişiklikler konusunda yabancı yazarların ruhu duymuyor ama yerli yazarlarda da kendi yönetmenlik alanımı önemsiyorum. Yazarı da orada yokmuş ve sadece prömiyere gelecekmiş gibi hayal ediyorum.

Murat Mahmutyazıcıoğlu: Bazı yönetmenler yazarları provalara kesinlikle sokmuyorlar. Ben Fü'nün de, Aynur Hanımın Bebeği'nin de, Sevmekten Öldü Desinler' in de birçok provasına gittim. Burada alanları ayırmak çok önemli ama elbette süreç de önemli. Son provaların birinde şöyle söylemiştim: "Ben ölü yazar değilim ve bu tekrar yazılabilir, tekrar düşünülebilir," çünkü bu yeni yazılmış bir metin ve araştırma alanı var ve henüz insanlar bu metni bilmiyor. Daha çağdaş düşünürsek yazar oyuncuyla birlikte metni değiştirebilir, yönetmene alan açabilir. Egoların arındırılması gereken yaratıcı bir ortam oluşturulması gerekiyor. Biz bunu yavaş yavaş öğreniyoruz.

Sami Berat Marçalı: En çok yaptığımız hatalardan öğreniyoruz. Yaptığımız iyi şeylerden o kadar öğrenmiyoruz. Dinlemek, almak ve açık olmak çok önemli.

Soru: Dramaturjiye yaklaşımınız nedir? Yönetirken dramaturgla çalışıyor musunuz ve yazdığınızı gönül rahatlığıyla dramaturga emanet edebiliyor musunuz?

Murat Mahmutyazıcıoğlu: Oyuncu olarak yer aldığım bazı oyunlarda bir dramaturji çalışması yapıldı. Şimdiye kadar çok oyun yönetmedim. Kendi oyunlarımdan iki tane ve bir de Sami'nin oyununu yönettim. Bu oyunlarda bir dramaturgumuz yoktu ama metnin geliştirilmesi adına birçok insandan fikir alındı. Bahsettiğiniz gibi bir çalışmanın içinde olmadım şimdiye kadar bu nedenle dramaturg ne katar ya da ne eksiltir bunu cevaplayamayacağım. Samimiyetle 
söylemem gerekirse belki daha çok kendi metinlerimi yönettiğim için, dramaturgun yeri benim kafamda soru işareti.

Sami Berat Marçalı: Dramaturgla birebir çalışmanın ne demek olduğunu biliyorum ama bugüne kadar hiç çalışmadım. Çalışmam gerekir bence ama kaç açık ve donanımlı dramaturg var bilmiyorum. Bence temel eksiğimiz bu noktada başlıyor. Kaç tane donanımlı dramaturg tanıyoruz ki? Kendilerine dramaturg diyen insanlar var ama işlerini hiç görmedim ve onlara ne kadar güvenebileceğimi bilmiyorum. Oyun sahnelenirken dramaturgun yanımda olmasını anlamıyorum. Ama oyunun dramaturjisinin yapılmasının ne demek olduğunu biliyorum. Dramaturgun muhakkak etkisi vardır ama süreçte ne gibi bir anlamı var tam olarak anlamadım.

Soru: Ne kadar donanlımlı dramaturg var ki derken ve dramaturjinin sadece metin odaklı olduğunu bize söylerken tam olarak ne demek istediniz? Sahnedeyken yönetmenin yanında dramaturg ne yapar dediğinizde dramaturgun sadece karakter analizi yapabileceğini mi düşünüyorsunuz?

Sami Berat Marçalı: Söylemek istediğim şey; dramaturgla dramanın bütün alanlarını tartışıyor olmak. Bir oyun yazarken dramaturgun işlevini anlıyorum ama yönetirken anlamıyorum.

Soru: İleriye dönük planlarınız arasında hem yazıp hem yönetip hem de oynamak gibi bir amacinız var mi?

Murat Mahmutyazıcıoğlu: Yazdığım oyunda oynamak gibi bir düşüncem yok. İlk yaptığım oyunda bunu denedim ve çok zevksiz oldu. Çünkü sürekli kendinizi izliyorsunuz. Tabi ki bunu çok iyi yapan insanlar var. Bu tecrübeyle de alakalı bir durum. Ama ben daha çok yazdığım şeyi yönetirken dişarıda olup oyuncularla uğraşmayı seviyorum.

Soru: Yazdığınız zaman kafanızda oyuncuya dair bir şey oluşuyordur muhakkak ben bu serüveni merak ediyorum. Örneğin ufak bir ekipseniz zaten oyunu yazarken kimin oynayacağını biliyordur yazar.

Sami Berat Marçalı: Bir oyunu yazarken bir oyuncuyu düşünerek yazmıyorum. Kendim bir şey kurup ondan sonra hayal ettiğim karakterleri bulmaya çalışıyorum. Daha doğrusu bu yazdığım karakterleri benden daha iyi anlayabilecek oyuncuları arıyorum. Bazen karşına karakterleri senden daha iyi anlayabilen biri çıkmıyor. Bu noktada da en iyi anlayabilecek potansiyeli olanı seçiyorsun.

Murat Mahmutyazıcıoğlu: Bazen bir oyunu yazarken belli bir oyuncuyu düşünerek yazdı̆̆ım oluyor. Örneğin Sen İstanbul'dan Daha Güzelsin'i yazarken Melis karakterini Melis oynayacak gibi yazmaya başlamıştım çünkü onun oynayacağı kesinleşmişti. Ama diğer karakterleri seçerken sorunsuz bir şekilde çalışabileceğim ve oyunculuklarına güvendiğim arkadaşlarımı tercih ediyorum. 
Soru: Konuşmanın başında tiyatroyu ve edebiyatı farklı yerlere koyduğunuzu söylemiştiniz. Şu sıralar izlediğim oyunlarda edebiyat uyarlamalarını sıklıkla görüyorum. Bu durumda tiyatronun söz ile ilişkisi hakkında ne düşünüyorsunuz?

Sami Berat Marçalı: İkisi birbirinden farklı sanat dalları ve yazım şekilleri de farklı. Birinde sen tek başınasın ve yazdıklarını kağıda döküyorsun, sonra insanlar okuyor ve hayal gücünde canlandırıyorlar. Diğerinde de yazıyorsun ve provayla ayağa kalkmış halini insanlara izletiyorsun. Tiyatro o anda ve orada gerçekleştiği için bunun edebiyat olmadığına inanıyorum.

Soru: Bir seyirci kitleniz oluştu ve bu kadar insana ulaşmışken bu aşamadan sonra kurumsal tiyatrolarla ilişkiniz nasıl olacak? Bu kurumlardan size oyun yazmanız ya da oyunlarınızın sahnelenmesi için teklifler geliyor mu?

Sami Berat Marçalı: Tabi ki geliyor ama örneğin Devlet Tiyatrosu'ndan teklif geldiği zaman bazı şeyleri elememizi istiyorlar. Baştan zaten herhangi bir küfür ya da LGBT birey dışarıda kalıyor. Bu nedenle benim ilgimi çekmiyor. Daha özgürlükçü davranan bir kurum varsa -şu an BBT öyle- oralarda elbette çalışmak isterim.

Murat Mahmutyazıcıŏglu: Bizde sanatla alakası olmayan tuhaf koşullar var. "Bu karakteri oyundan çıkaralım” gibi bir şey bana da söylendi. Bence bir yapımcının yazara böyle bir şey söyleme gibi bir alanı olmamalı ama kolaylıkla söyleniyor. Çünkü yazarlar bunları duymaya çok alışık. Ama hayatlarını devam ettirebilmek için bu çarkın içine giriyorlar. Çok kötü ve çirkin bir durum. Bir sanat içinde böyle bir yasak durumunu kabul edemiyorum. Bu nedenle aç kalsam da kendi tiyatromda işimi yapmaya devam edeceğim. Bu sansür ve yazarın yaratıcı alanına girilmesi meselesi o kurumları çürüttü. Belki de yeni bir şeyin başlaması için bir şeylerin yıkılması gerekiyor. Bizin, sizin ya da buranın var olmasının nedenlerinden biri de bu çürüme.

Soru: Dramaturji diye bir bölüm var. Bu bölümü bitirenler ne oluyor?

Murat Mahmutyazıcıŏglu: Son dönemde okuduğum bütün sağlam eleştiri yazılarının hepsi dramaturji mezunları tarafından yazılmış oluyor. Bir insanın tiyatro yazıyor oluşu, tiyatro eleştirisi yazıyor olduğu anlamına gelmiyor. Metnin kurgusuna, oyuncunun ya da yönetmenin onu nasıl yaptığına yönelik eleştiriler birkaç senedir dramaturji mezunları ya da öğrencileri tarafından yazılıyor. Dramaturglarla projelerde beraber olmasak da yazdıkları eleştirilerin bana çok yararı oldu.

Ozan Ömer Akgül: Bir sonraki söyleşimizi 8 Nisan Pazar günü yapacağız. Berkay Ateş ve Halil Babür ile konuşacağız. Katıldığınız için teşekkür ediyoruz. 